\title{
FORMULA STUDENT VERSENYAUTÓ ELEKTROMOS RENDSZERÉNEK FELÉPÍTÉSE
}

\author{
Koba Máté \\ egyetemi tanársegéd, Miskolci Egyetem, Automatizálási és Infokommunikációs Intézet \\ 3515 Miskolc, Miskolc-Egyetemváros,e-mail: kobamate@uni-miskolc.hu
}

\begin{abstract}
Absztrakt
Ebben a cikkben egy Formula Student versenysorozaton résztvevö versenyautó elektromos rendszere kerül bemutatásra. A versenysorozat ismertetése után a Miskolci Egyetem csapata, a Formula Racing Miskolc rövid ismertetöje következik. A szabályrendszer ismertetése után bemutatásra kerül a csapat által fejlesztett versenyautó, külön kiemelve annak elektromos rendszerét, kezelöszerveit. Az autóban egyedi akkumulátor felel az energiaellátásért, igy az is bemutatásra kerül a fö villamos vezérlöáramkör és az elektromos kuplungrendszer mellett. A jelenlegi fejlesztések után a cikkben ismertetésre kerül a csapat jövöbeli terve az elektromos és önvezetö jármüvek fejlesztésével kapcsolatban.
\end{abstract}

Kulcsszavak: formula student, versanyautó, elektromos kuplung, akkumulátor, nyomtatott áramkör

\begin{abstract}
In this article, the electrical system of a racecar will be introduced which is taking part in the Formula Student competition series. After introducing the series, the team from University of Miskolc, called Formula Racing Miskolc will be introduced briefly. After explaining some parts of the competition rules, the racecar developed by the team will be introduced, paying extra attention for the car's electrical system and control parts. In the car, a custom-made battery system is supplying all the electrical consumers, so this system will be also introduced in addition to the main control circuitry and electrical clutch actuation. After describing the ongoing and finished developments, the future plans will be introduced according to the electrical and driverless racecars.
\end{abstract}

Keywords: formula student, racecar, electrical clutch, battery, printed circuit

\section{Bevezetés}

A Formula Student versenysorozat már több, mint 20 éve van jelen Európában. A verseny világszerte jelen van, jelenleg több, mint 600 csapat vesz részt ilyen versenyen. A verseny célja nem csak egy versenyautó fejlesztése, hanem a projekt menedzselése is, ami nem csak mérnökhallgatóknak nyújt egyedülálló fejlődési lehetőséget. A Formula Racing Miskolc csapat 2013-ban alakult, tagjai a Miskolci Egyetem hallgatói. A csapat tagjai kizárólag a Miskolci Egyetem hallgatói, a tagok között alapképzésben és mesterszakon résztvevő hallgatók is jelen vannak, javarészt a Gépészmérnöki és Informatikai kar hallgatói, a szakokat tekintve Gépészmérnök, Jármümérnök, Mechatronikai mérnök, Mérnökinformatikus, Müszaki menedzser, Programtervező informatikus és Villamosmérnök szakos hallgatók. Az utóbbi években a média és humán tevékenységeket erősítendő, a Gazdaságtudományi kar hallgatói is erősítik az egyetem csapatát. A versenysorozat 2020-ig 3 kategóriában volt jelen, ezek a CV (belsőégésủ motoros), EV (elektromos hajtású) és DV (önvezető) kategóriák. 2021-től, az ipari trendek követése céljából a versenysorozat megszüntette a különálló önvezető kategóriát és megkezdte 
az önvezető versenyszámok beintegrálását a CV és EV kategóriákba. A Miskolci Egyetem csapata a CV kategóriában kezdte a versenysorozatot, 2019-ben pedig elkezdett felkészülni az elektromos kategóriában történő versenyzésre, 2020-tól pedig elkezdődött a csapaton belül az első elektromos versenyautó, az FRMe-01 fejlesztése. A cikk részletesebben a harmadik belsőégésủ motorral szerelt versenyautót, és annak „b” változatát taglalja részletesebben, név szerint ezek az FRMc-03 és FRMc-03b típusjelüek.

\section{Szabályzat}

A versenysorozat során a csapatok saját fejlesztésủ versenyautókkal versenyeznek, ezek pilótái szintén hallgatók, így emiatt a fejlesztéseket szigorú szabályrendszerhez kötik, így lehetővé téve a biztonságos, ugyanakkor élvezetes versenyzést. A szabályzat előtérbe helyezi a biztonságos versenyzést, így az autók a lehető legbiztonságosabb kialakításúak, azokat a versenyek előtt gépátvétel során ellenőrzik is.

Néhány főbb korlátozás:

- belsőégésü motor esetén a maximális lökettérfogat $710 \mathrm{~cm}^{3}$,

- belsőégésủ motor esetén a szívócsőbe szükséges beépíteni egy $20 \mathrm{~mm}$ átméröjü folytást,

- elektromos versenyautó bármely két elektromos pontja között a maximális feszültség 600 VDC [1].

A belsőégésü versenyautók elektromos rendszerére vonatkozó legfontosabb kikötéseket szemlélteti az 1. ábra.

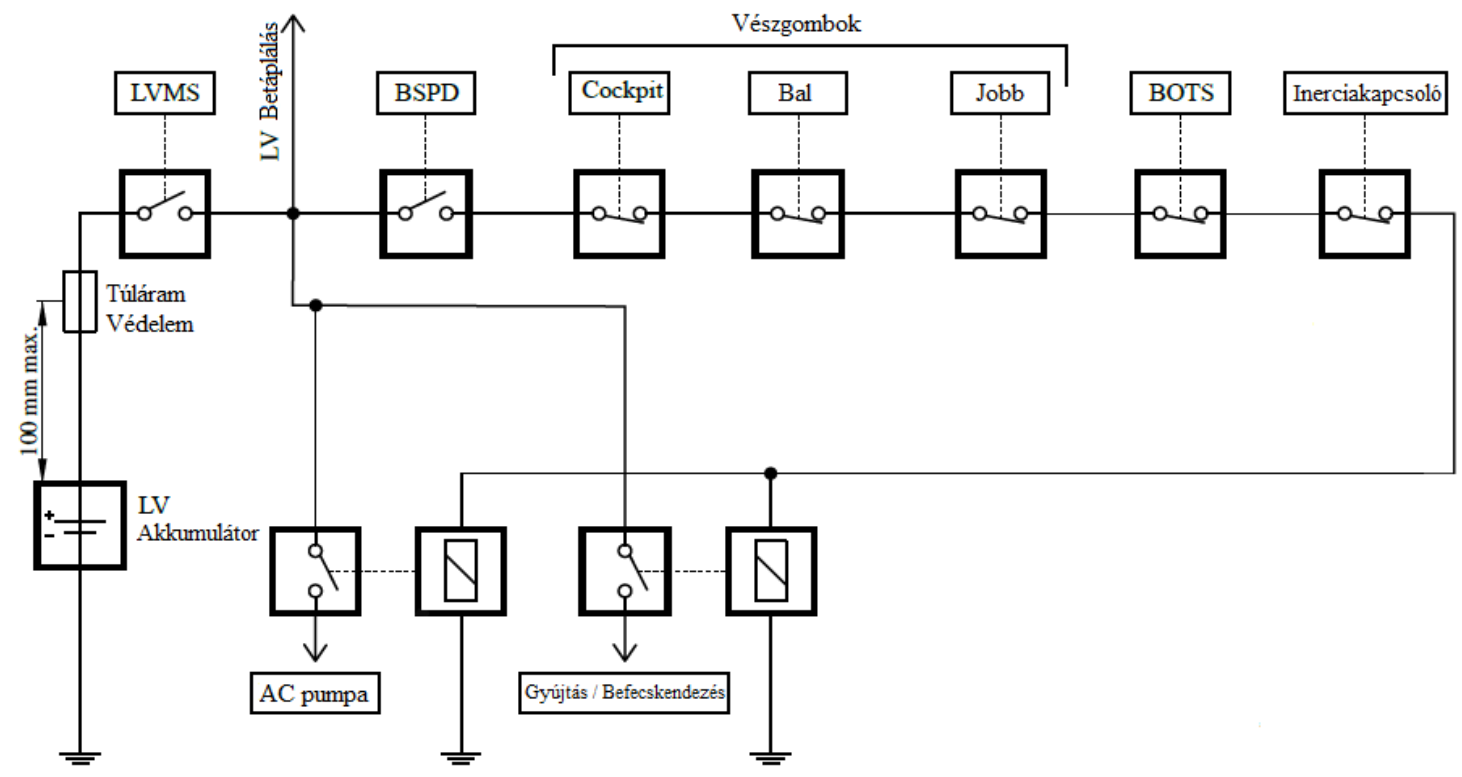

1. ábra. Vészleállitó rendszer [1]

Az ábrán használt rövidítések:

- LV - „Low Voltage” - alacsony feszültségü rendszer,

- LVMS - „Low Voltage Master Switch - alacsony feszültségü főkapcsoló,

- BSPD - „Brake System Plausibility Device” - fékrendszer elfogadhatósági vészleállító egység,

- BOTS - „Brake Over Travel Switch” - fékpedál beesési vészkapcsoló. 
A fenti ábra alapján jellemezhető a vészleállító áramkör müködése. Az elektromos rendszert az alacsonyfeszültségü főkapcsoló teljes mértékben áramtalanítani képes. Az autón 3 vészleállító gomb található, melyet külső személy vagy a pilóta müködtethet, ezekből $1 \mathrm{db}$ a pilóta közvetlen közelében, 11 pedig a bukócső két oldalán helyezkedik el. Az autóban elhelyezkedik egy inerciakapcsoló is, mely akkor old ki, amikor egy adott határértéknél nagyobb gyorsulás éri az autót. Található még egy vészleállító a fékpedál alatt, ami akkor szakítja meg a vészleállító áramkört, amikor valamilyen hiba okán a fékrendszer nyomása lecsökken és a fékpedál beesik. A BSPD egy olyan biztonsági áramkör, ami a folytószelep helyzetét és a fékrendszer nyomását figyeli, majd megszakítja a vészleállító áramkört, amikor erős fékezéskor a folytószelep $25 \%$-nál nagyobb mértékben nyitva van.

A vészleállító áramkör zárt állapotban lehetővé teszi a befecskendezés, gyújtás és üzemanyag pumpa müködését, azonban amikor az áramkör megszakad, ezeket áramtalanítani kell. Az akkumulátor után továbbá szükséges beépíteni egy olvadóbiztosítékot, ami az akkumulátor maximális árama fölött old le. A versenyautóban a vészleállító berendezéseket az autó egyedileg tervezet és gyártott kábelkötege kapcsolja össze. A kábelköteg továbbá összeköti a motorvezérlőt (ECU) és a müszerfalat is a motor többi perifériájával. Az áramkörben müködő reléket és az egyéb vezérlő logikákat egy fö vezérlő áramkör müködteti, melyet a cikk a továbbiakban részletesebben is bemutat.

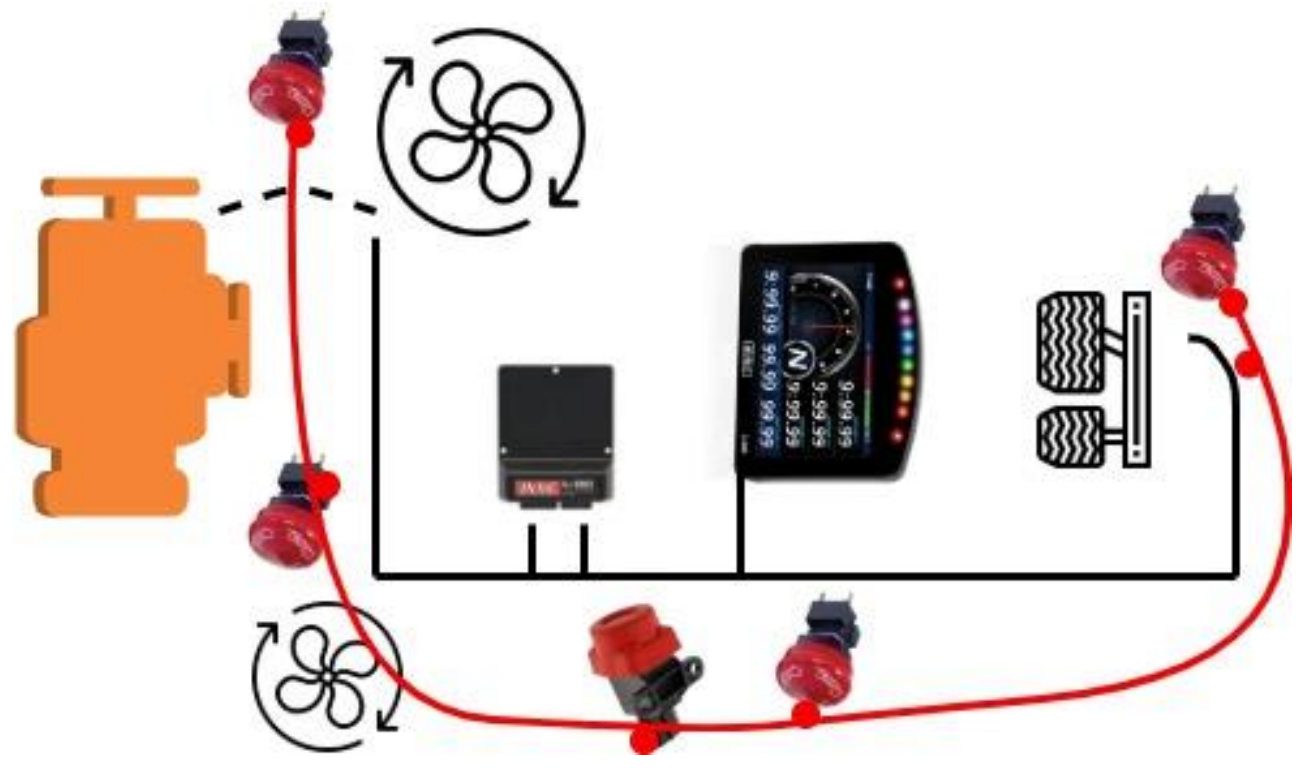

2. ábra. Vészleállitó áramkör és kábelköteg elhelyezkedése

A 2. ábra szemlélteti a főbb villamos fogyasztókat, a szabályzat szerint szükséges vészleállító áramkör elemeit, illetve a kábelköteg elvi elhelyezkedését. Az ábrán a szaggatott vonal a kábelköteg azon részét szemlélteti, amely a belsőégésủ motor müködtetéséhez szükséges beavatkozókhoz és szenzorokhoz tartozik, ezeket a cikk nem taglalja részletesebben.

\section{Belsőégésű motoros versenyautó elektromos rendszere}

A versenyautó villamos rendszerét egy központi egység vezérli, ennek belsejében kapott helyet az akkumulátor is, így a kábelköteg minden vezetéke erre a központi helyre csatlakozik be. Az elektromos dobozban található továbbá a motorvezérlő egység, illetve a fö villamos vezérlöáramkör is. 


\subsection{Akkumulátor}

A villamos fogyasztók energia ellátásához szükség volt egy saját tervezésủ akkumulátor összeállítása, ugyanis a jelenleg piacon kapható akkumulátorok mérete nem ideális egy kisméretủ versenyautóba történő beépítésre. Az akkumulátornak el kell tudnia látni a villamos fogyasztókat álló helyzetben, amíg a generátor nem biztosítja azt járó motor mellett. Az akkumulátornak továbbá kellően nagy kapacitásúnak kell lennie ahhoz, hogy egy verseny során a lehető legtöbb indítást lehetővé tegye anélkül, hogy azt az indítások között tölteni kelljen. Ezen kritériumok mellett a lehető leg könnyebbnek kell lennie, így a hagyományos, burkolattal rendelkező akkumulátorok nem megfelelőek egy ilyen alkalmazásra. Az autóban alkalmazott akkumulátor LiFePo4 összetételü cellákból áll, 4s3p elrendezésben. Elkészült egy nagyobb, 4s4p (10 Ah) elrendezés is, arra az esetre, ha a kisseb kapacitású (7.5 Ah) akkumulátor nem elegendő a hosszútávú müködtetéshez.

\subsection{Vezérlő rendszer}

Az autó vezérlő rendszere 2 fö részre osztható, az egyik a motorvezérlő által vezérelt részegység, ami a befecskendezőszelepeket, gyújtótranszformátorokat és a belsőégésủ motor müködtetéséhez szükséges egyéb perifériákat vezérli, a másik rész pedig a villamos dobozban található mikrovezérlő által vezérelt rész. A továbbiakban az utóbb említett részegység feladatait mutatja be részletesebben a közlemény.

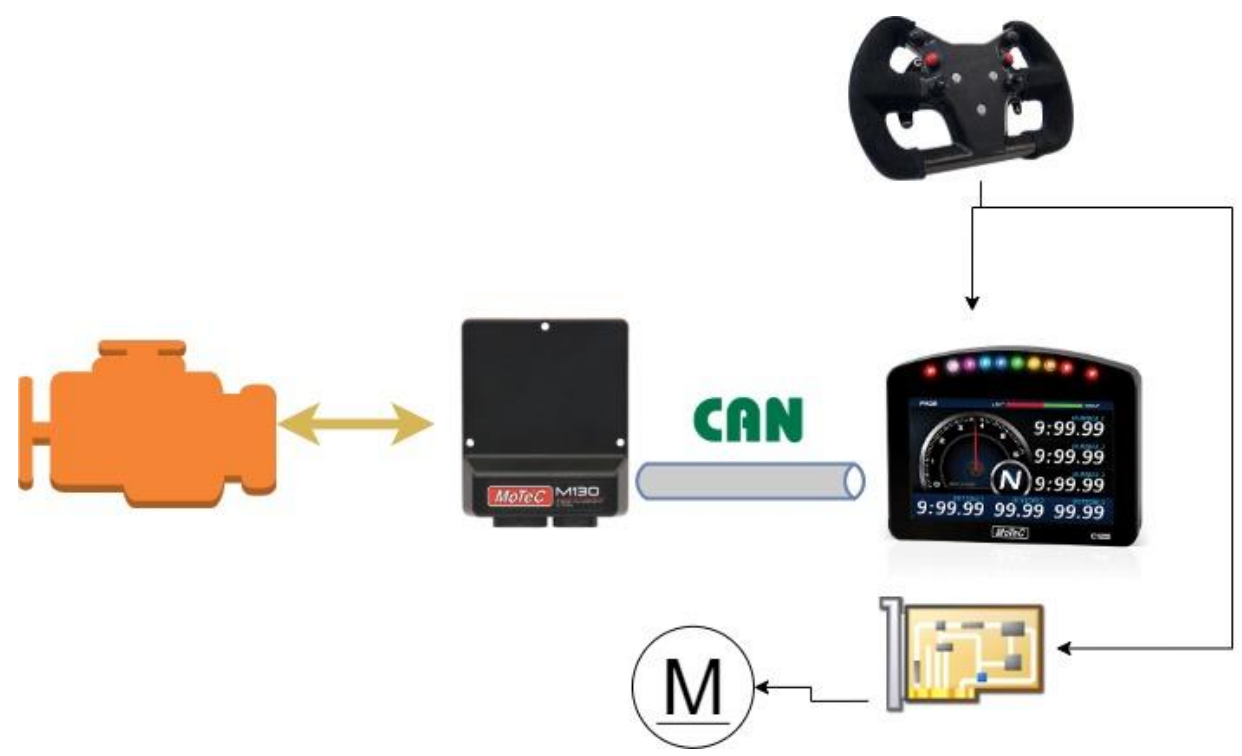

3. ábra. A versenyautó villamos vezérlörendszere

A 3. ábrán látható a villamos vezérlő rendszer sematikus felépítése. A motorvezérlő és a megjelenítő egység CAN-en keresztül kommunikál egymással, az autó CAN rendszerén lekérdezhető a motor és annak érzékelőinek, perifériáinak állapota. A motorvezérlő rendszer mellett a másik részegység a mikrovezérlő egység, ami a kormány perifériái alapján vezérli az elektro-mechanikus müködtetésü tengelykapcsolót. 


\subsubsection{Motorvezérlö}

A motor vezérlése egy MoTeC M130 motorvezérlő feladata, amely CAN-en keresztül kommunikál az autó kijelző moduljával. A motorvezérlő a motor múködtetése és a szenzorok adatainak feldolgozása mellett vezérli a vízhűtő ventilátort, üzemanyagpumpát, vízpumpát és a váltáshoz használt elektropneumatikus rendszert.

\subsubsection{Kijelzö modul}

Az autó müszerfalán elhelyezésre került egy kijelzőmodul, ami fontos információkat közöl a pilótával verseny közben. Az FRMc-03 és FRMc-03b-ben használt kijelző egy MoTeC C125 típusú egység. A kijelző modul több nézetet tud megjeleníteni, amiket a motor melegítésénél, tesztelésnél, illetve verseny közben optimalizált elrendezésben lehet használni.

\subsubsection{Fö villamos vezérlöáramkör}

Az autó elektromos fogyasztóinak áramellátásáért és a biztonsági vészleállító áramkör megszakításáért egy föáramkör felel. Ezen az áramkörön helyezkednek el a fogyasztókat kapcsoló relék, szervomotorokat megtápláló DC-DC konverterek, és az azokat vezérlő mikrovezérlő egység.

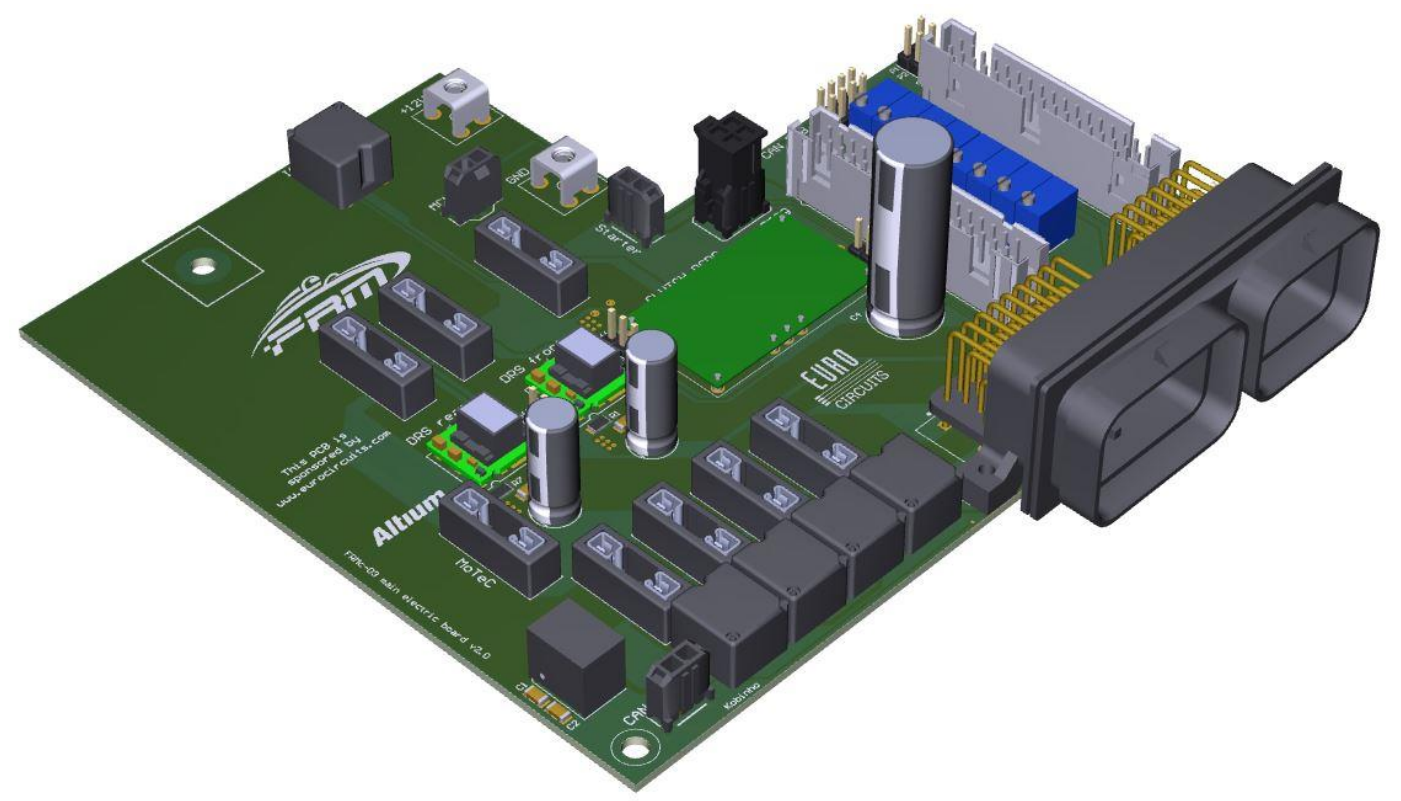

4. ábra. Fö vezérlöáramkör

A 4. ábrán látható a villamos vezérlőáramkör 3D modellje. Az áramkör kialakítása a tápfeszültség elosztásán kívül a telemetria rendszer jeleinek továbbítását, a kuplung aktuátor és a majdani DRS aktuátorok megtáplálását is. Az áramkör az alacsonyfeszültségü fökapcsolóról kapja a tápellátást, a ki és bemenő jelek vezetékei pedig egy vízálló motorsportcsatlakozón keresztül csatlakoznak az áramkörhöz. A nagyobb áramot ( $\geq 1 \mathrm{~A})$ átvezető vezetősávok méretezése a vonatkozó elöírások figyelembevételével megtörtént, kialakításuk ezeknek megfelelően lett kiképezve [2] [3]. 


\subsubsection{Elektromechanikus tengelykapcsoló aktuálás}

A kuplung jelenlegi működtetése hidraulikus rendszerrel történik, a müködtető kar a pilóta jobb oldalán helyezkedik el, az autó csővázához rögzítve. Elindulásnál a pilóta egyik kézzel a kuplungot müködteti, másik keze pedig a kormányt kezeli, ez sok esetben kényelmetlen, illetve nehezítheti az elindulást. Az elektromos kuplung lehetővé teszi, hogy a kormányon elhelyezett kuplungkar által továbbított villamos jel segítségével legyen vezérelve a tengelykapcsoló, így induláskor a pilóta mindkét keze a kormányon lehet, megkönnyítve az autó kezelését rajtoláskor. A kuplungkar jelét egy megfelelően pozícionált potenciométer biztosítja. A potenciométer tengelye mindössze $\sim 5^{\circ}$-ot fordul a teljesen zárt és nyitott állás között, így szükség volt egy logaritmikus potenciométer beépítése oly módon, hogy az a karakterisztikájának meredek tartományában legyen müködtetve, így egy kisebb mozdulatra is nagyobb mértékü feszültségváltozás történik, ami megkönnyíti a jelfeldolgozást. Az analóg jelet egy SMT32F103CCT6 típusú mikrovezérlő dolgozza fel, ami egy $50 \mathrm{~Hz}$-es PWM jelet előállítva hozza müködésbe a tengelykapcsolót aktuáló szervomotort. A motor gyújtása által keltett elektromos zaj a vezérlő jelen kismértékủ torzítást eredményezett, ezt kiküszöbölendő a potenciométer analóg jelének feldolgozása egy mozgóátlag számítással és a jelvezetékre illesztett aluláteresztő szürőtag beiktatásával történt.

\section{4. Összefoglalás}

A cikk bemutatta a Miskolci Egyetem hallgatói által, a Formula Student versenysorozatra fejlesztett versenyautó elektromos rendszerét, a szabályzat vonatkozó részeit ismertetve bemutatásra került a vészleállító áramkör, akkumulátor, fö vezérlő áramkör és az elektromechanikus kuplung. Látható, hogy az autó elektromos rendszerének fejlesztése során különös figyelmet kell fordítani annak elektromos kötegére, a vezetékek méretezésére és a szakszerủ gyártásra. Az akkumulátor méretezése szintén egy kritikus pont a fejlesztés során, ugyanis a nem megfelelően megválasztott akkumulátor elrendezés meghibásodáshoz vezethet. A versenyautóhoz méretezett akkumulátor az eddig végzett tesztek során megbízhatónak bizonyult, nem szükséges nagyobb kapacitásúra cserélni. Az elektromos kuplung szintén egy kritikus pont a sikeres versenyzés tekintetében, ugyanis elinduláskor a pontos vezérlés megkönnyíti a pilóta munkáját. Az esetleges meghibásodás verseny közben akár kieséshez is vezethet, így ezt a rendszert a legátfogóbb módon szükséges tesztelni az optimális működés érdekében. Mivel egy ilyen rendszer az autó motorja által közölt nyomatékot befolyásolja, így a szabályzat alapján ez egy kritikus rendszer, a meghibásodását detektálni kell, hibás müködés esetén az autó villamos vészleállító áramkörét meg kell szakítani. Összességében elmondható, hogy az FRMc-03 és FRMc-03b típusjelủ autók villamos rendszere az utóbbi versenyszezonok során megbízhatónak bizonyult, azonban fejlesztésekre így is lehetőség van. A továbbiakban az elektromos kuplung további tesztelése a cél a köteg újraépítése mellett, ahol optimalizálásra kerülnek a vezeték hosszak, keresztmetszetek és a köteg útvonalai, ami a tömegcsökkentésen kívül a megbízhatóságot növeli.

\section{Köszönetnyilvánítás}

A cikkben ismertetett kutató munka az EFOP-3.6.1-16-2016-00011 jelü „Fiatalodó és Megújuló Egyetem - Innovatív Tudásváros - a Miskolci Egyetem intelligens szakosodást szolgáló intézményi fejlesztése" projekt részeként - a Széchenyi 2020 keretében - az Európai Unió támogatásával, az Európai Szociális Alap társfinanszírozásával valósul meg. 


\section{Irodalom}

[1] Formula Student Rules, https://www.formulastudent.de/fsg/rules/

[2] IPC-2152, https://www.ipc.org/ContentPage.aspx?pageid=IPC-2152-Standard-forDetermining-Current-carrying-Capacity-in-Printed-Board-Design-Released

[3] Altium, online: https://resources.altium.com/p/using-ipc-2152-calculator-designing-standards 